\title{
Using Facebook Group in Teaching Writing Of English For Accounting Classes
}

\author{
Fitria Nur Hamidah ${ }^{1}$, Dion Yanuarmawan ${ }^{2}$ \\ Polytechnic of Kediri, Accounting Study Program \\ Kediri City, East Java Indonesia \\ fidahfnh@gmail.com ${ }^{1}$, dionyanuarmawan@gmail.com
}


Abstract Online social network especially Facebook has recently been perceived by the lecturer of English for Specific Purposes (ESP) as an alternative media for teaching writing. The aims of this study are to examine the kinds of writing teaching and learning activities in English for accounting class which carried out via Facebook and to describe the use of $\mathrm{FB}$ group in facilitating writing teaching and learning for English for accounting class based on the students" perception. Facebook (FB) group is a feature that is available on Facebook social networking site. This feature allows for an unlimited number of members to participate, communicate and interact via post and chat style especially for supporting ESP teaching and learning process. The FB groups which were created by the chief of the classes were usually used by the lecturer and the students in the class. Using Facebook (FB) group in teaching writing of English for Accounting class in Polytechnic of Kediri was very useful for the lecturer and the students of accounting.

Keywords: FB group, Teaching Writing, ESP, English for Accounting class.

\section{INTRODUCTION}

ICT (Information Communication Technologies) has a role in teaching and learning process. According to Kenning (2007), Current global developments especially in computer technologies have opened up more opportunities for educationists to design and implement Information Communication Technologies (ICT)-based lessons to make teaching and learning more interesting, motivating as well as meaningful. So ICT can help teaching and learning process.

One of technology development is social networking. Facebook is one of social media internet tools. It can be as a media in teaching and learning process especially in English for Specific Purposes teaching and learning process. English for Accounting teaching and learning process especially in writing skill needs Facebook group as a media.

In teaching writing of English for Accounting, the ESP lecturer intended to change the tradition of the accounting students to submit their assignments in a piece of paper. Besides, the ESP lecturer would like to make the accounting student who are enjoyful and fun in the class. They can use Facebook Group to submit their assignments in Facebook Group

\section{LITERATURE REVIEW}

Coffin et al (2002) states that Academic writing is at the centre of teaching and learning in higher education, fulfilling a range of purposes according to the various contexts including assessment, learning and entering particular disciplinary communities. In writing skill of English for Accounting classes, it is also used academic writing theory whether it is in having assessment and doing writing teaching and learning process. Besides, it also used social media especially facebook group in some activities in the classroom.

ICTs are becoming increasingly popular as a method of language instruction. Bartlett-Bragg (2006) describes social networks as a "range of applications that arguments group interactions and shared spaces for collaboration, social connections, and aggregates information exchanges in a web-based environment".

According to Terantino and Graf (2011), Social media sites provide a means of communication that is highly accessible to users across the globe. In addition, they allow users to participate in a collaborative form of knowledge construction, because they provide tools for creating and sharing information with others. In particular, Facebook is a social networking website that allows people to connect with other users through the exchange of profiles, conversation, photos, and videos.

Besides, Terantino and Graf (2011) states that as students become increasingly connected through social networking sites such as Facebook, it is important for us to explore how these can be utilized specifically in the foreign language classroom. Facebook provides a target-language-friendly interface created for and used by native speakers in a format familiar to students. As users connect, 
they are able to share Internet links and multimedia such as photos or videos with ease. This could allow the instructor to facilitate discussion among students of target language and culturally relevant material.

Friedman \& Friedman (2012) argues that "the best way to bring courses to life and make learners more exciting, energetic, and enjoyable is by using social networking site in their learning". Furthermore, Majid, Stapa, \& Keong (2012) state that "Facebook is a social networking site which can be utilized as an educational technology tool that facilitates online communications between second language learners and their friends".

Roberts (2009) emphasizes the reasons why Facebook is obviously promising for the foreign language classroom in four ways: (1) Facebook is internet based, it can be accessed simply by cell phones, (2) many students have been using Facebook actively, so teachers do not need to explain in detail how to use it, (3) Facebook is always free; to use it, students only need to have e-mail address and internet access, and (4) Facebook is ideal for out-of-class time, it keeps valuable class time available for other important activities.

The researcher then also believes that FB, and specifically FB groups, has the potential to improve students ${ }^{\text {ee }}$ writing skills by being the link between academic "writing" and outside "communication", providing learners with an authentic and personalized context in which to aid their writing. „FB groups ${ }^{\text {ee }}$ provides ample opportunities for students to practice and improve their writing skills. Studies show that students feel obliged to respond to their peers "e comments or opinions posted, thus are actively "posting" and "commenting" on the application. They take every opportunity to practice their writing skills.

\section{RESEARCH METHODOLOGY}

This study used descriptive qualitative design and this study was based on the nature of situation that the researcher described, it was the use of FB group in teaching writing of English for accounting classes, Polytechnic of Kediri. The subject of this study was the students of Accounting who got English for Accounting subject, they are in Accounting 3B Class and Accounting 3D class. The data was taken from the ways of teaching methods that were used by the ESP lecturer in teaching writing and the students ${ }^{\text {ee }}$ perception in using Facebook Group.

In collecting the data, the researcher employed some steps. First, the researcher entered the classes to do English for accounting teaching and learning process to the students of Accounting, Polytechnic of Kediri. Second, the researcher used Facebokk group as the media in teaching writing as usual activity especially in asking the students to submit their writing. Third, the researcher did an interview to the students who were learned English for Accounting in their classes randomly. Then, selecting the data related to the purpose of the study is the last step in collecting the data.

After the data had been obtained and studied, the researcher took several steps to analyze the data. The researcher analyzed it based on the data that were collected. The researcher identified the results especially the development of writing skill in English of Accounting teaching and learning process. Then, the researcher analyzed the data based on the students ${ }^{\text {ee }}$ perception especially in using Facebook group in teaching writing skill of English for Accounting. The last is the researcher did evaluation based on the results of the observation in her teaching learning process.

\section{FINDINGS}

The findings are divided into two. First is the explanation about the kinds of writing teaching and learning activities in English for accounting class which carried out via Facebook especially for Facebook Group. 
Second is the description about the use of FB group in facilitating writing teaching and learning for English for accounting class based on the students ${ }^{\text {ee }}$ perception.

\section{Writing Teaching and Learning Activities}

There are four types of writing activities of English for Accounting recognized in this study which are pre-writing activities, writing the draft, responding and review and revising and editing. Under the topic of Micro and macroeconomic, the lecturer asked the students to make a paragraph. Prior to that activity, the students encouraged to read some theories about micro and macroeconomic. It would be as brainstorming session and discussion before they start to write with their friends. The outcomes from the discussion were recorded and developed as the outline of their writing. Then, the students prepared the outline and uploaded it to the Facebook group to be checked by the lecturer.

This activity promotes the students to have proper beginning to their paragraph writing. By reading other studentse outlines, it helped the students to amend, re-arrange ideas for a better paragraph write-up.

In the process of writing the draft, the students had gone through several phases of planning and writing that needed them to get approval from the lecturer. In other words, this process was started in the class and continued in the Facebook. The lecturer and the students themselves can look at the drafts uploaded through the "files uploaded" features.

The third activity identified from the writing activities was responding and reviewing other students ${ }^{\text {ee }}$ work. The students required to choose the first draft posted by their friends to review and give comment. They could give comments each other. Their comments in facebook group were useful to revise their paragraph writing before they submit to the lecturer.

The forth activity is revising to submit a good paragraph to their lecturer via Facebook group. They submit their paragraph after they got comments from their friends. So teaching writing activities which were done by the researcher in the classroom.

\section{The use of FB group in facilitating writing teaching and learning}

Based on the students ${ }^{\text {ee }}$ perception, facebook was definitely beneficial to the accounting students attempting to improve their English writing skills. This was substantiated by the fact that the accounting students could write at their own pace, exchange writing samples among each other freely and spend as much time as they need brainstorming. All of this helped the students in their pre- writing activities well before they become ready to compose the final version of their paragraph writing to be submitted to the lecturer for final evaluation.

Besides, Majority of the students agreed that the comments from their friends were useful, helped them to increase knowledge and assisted them in correcting their mistakes in writing. In addition, the students suggested that the comments helped them in changing the writing style, act as reminder of the errors and gave confidence to submit it to the lecturer. Moreover, the students liked if their works or documents were uploaded and were read by their friends and lecturer via facebook group. This activity was considered as helpful to them in providing feedback from their friends and also from the lecturer. The students also felt enjoyful, fun and more focus on their paragraph writing because they used facebook group in the classroom.

\section{DISCUSSION}

By giving some activities in teaching writing which was done by the researcher, it promotes the accounting students to have proper beginning to their writing. By reading other students outlines, it helped the students to amend, re-arrange ideas for a better research write-up. It relates to Flower and Hayes (cited in Hedge: 2000) contributed to the understanding of planning when they 
suggested that it goes on at many levels and throughout the process of composing.

Besides, the students claimed that this task is challenging for them as it required a careful revision depends not only on the studentse skill but also on the purpose of the writing (academic writing) and formality required to write it (Hedge, 2000). Overall, the findings also showed the improvement of students ${ }^{\text {ee }}$ positive behavior. The accounting students of those classes became more attentive, active, happy, joyful, and serious during the lesson. It indicated that the students were more motivated to learn.

\section{CONCLUSION AND SUGGESTION}

Based on the findings of this research, the use of Facebook group in teaching writing for English for accounting students was found that most of students gave positive response to the use of Facebook group in their learning. They believed that Facebook group could be benefitted as media in learning a paragraph writing especially in English for Accounting. They also liked the use of Facebook group as media in learning writing of English for Accounting. Furthermore, they felt that the use of Facebook group as media was very effective. The application of Facebook group as media of learning writing English for Accounting was quite easy. Finally, they agreed that Facebook group was needed to be used in their class activities.

$$
\text { Moreover, the efficacy of }
$$

Facebook supported writing skill of English for Accounting teaching and learning process in comparison with traditional learning, it was found that most of students agreed that using Facebook group in learning writing is better than traditional learning. They agreed that the use of Facebook group as media of writing a paragraph was more effective than using paper. Using Facebook group as writing media was more fun compared with using paper. In addition, learning using Facebook group enabled them to learn anywhere and anytime. Furthermore, students felt freer to comment on others ${ }^{\text {ee }}$ writing on Facebook group rather than in face to face classroom activity.

The suggestions are given to the lecturers and the students. It is suggested to the lecturer as ESP lecturer to facebook group when she teaches the students in the English for Accounting class to make the students feel enjoyful and fun in the classroom. The lecturer also has to know that facebook group can be used as prominent media in teaching learning process and it was also one of the ways or one of the strategies to deliver knowledge to the students in the classroom. So the ESP lecturer can apply the use of facebook group in every class when she teaches the students in the classroom. For the next or future researchers, the researcher hopes that they can use facebook group not only in the writing skill teaching and learning process in Polytechnic of Kediri but also other English skills such as reading, speaking and listening. Besides, the researcher hopes that the future researchers can use other social networking as a media in English for Specific Purposes teaching and learning process.

\section{REFERENCES}

[1] Ary, D., Jacobs, L.C. \& Razavieh, A. 2002. Introduction to Research in Education. Sixth Edition. Canada: NorthernIllino University.

[2] Bartlett-Bragg, A. (2006). Reflections on Pedagogy: Reframing Practice to Foster Informal Learning with Social Software. Retrieved from http://matchsz.inf.elte.hu/TT/docs/Anne20 Bartlett-Bragg.pdf [accessed on June, 2017].

[3] Bogdan, R.C. \& Biklen, S.K. 2007. Qualitative Research for Education. Fifth edition. New York: Syracuse University.

[4] Coffin, C., Curry, M. J., Goodman, S., \& Hewings, A. (2002). Teaching Academic Writing. Routledge, New York.

[5] Friedman, L. W. \& Friedman, H. H. 2012. Using Social Media Technologies to Enhance Online Learning. Online. Available at http://www.thejeo.com/Archives/Volume1 0Number1/Friedman.pdf [accessed on June 2017] 
[6] Hedge, T. (2000). Teaching and Learning in The Language Classroom, Oxford University Press.

[7] Kenning, M. (2007). ICT and Language Learning: From Print to the Mobile Phone. New York: Palgrave Macmilan.

[8] Majid, A.H.A, Stapa, S.H, \& Keong, Y.C. 2012. Blended Scaffolding Strategies through Facebook to Aid Learning and Improving the Writing Process and Writing Performance. IOSR Journal of Humanities and Social Science (IOSRJHSS) Volume 1, Issue 4 (Sep-Oct 2012), Pp 36-40. Online. Available at www.iosrjournals.org [accessed on June, 2017]

[9] Roberts, W.G. 2009. Facebook Interactions and Writing Skills of Spanish Language Students. Thesis. Concordia College.

[10] Terantino, Joe \& Graf Karen. 2011. Using Facebook in the Language Classroom as Part of the Net Generation Curriculum. California: Kennesaw State University, Kennesaw, GA. 